\title{
WestVirginiaUniversity
}

THE RESEARCH REPOSITORY @ WVU

West Virginia Agricultural and Forestry Experiment

Davis College of Agriculture, Natural Resources

Station Bulletins

And Design

$1-1-1956$

\section{Locating outstanding bulls in artificial breeding}

Robert Standish Dunbar

G. Heebink

Follow this and additional works at: https://researchrepository.wvu.edu/ wv_agricultural_and_forestry_experiment_station_bulletins

\section{Digital Commons Citation}

Dunbar, Robert Standish and Heebink, G., "Locating outstanding bulls in artificial breeding" (1956). West Virginia Agricultural and Forestry Experiment Station Bulletins. 386T.

https://researchrepository.wvu.edu/wv_agricultural_and_forestry_experiment_station_bulletins/636

This Bulletin is brought to you for free and open access by the Davis College of Agriculture, Natural Resources And Design at The Research Repository @ WVU. It has been accepted for inclusion in West Virginia Agricultural and Forestry Experiment Station Bulletins by an authorized administrator of The Research Repository @ WVU. For more information, please contact ian.harmon@mail.wvu.edu. 
West Virginia University Libraries

(i)

(1)

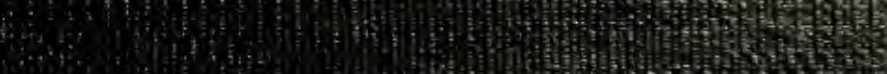

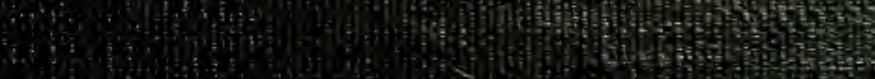

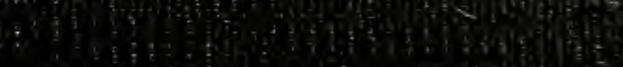

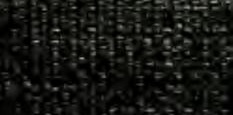


Digitized by the Internet Archive in 2010 with funding from Lyrasis Members and Sloan Foundation 


\section{BULLETIN 386T January 1956}

\section{Locating Outstanding Bulls}

in Artificial Breeding 


\section{Summary}

Previous reports have shown the need for progeny testing prospective young bulls in artificial breeding in order to make any appreciable progress in the improvement of a bull stud. The most promising group of young bulls for testing are those sired by outstanding A.B. proven bulls and out of highly selected dams. In most artificial breeding associations the number of such young bulls resulting from chance matings is inadequate. It is suggested that planned mating of selected A.B. proven bulls and highly selected cows is an expedient source of prospective young bulls. A procedure is described for locating outstanding A.B. proven bulls to be used as selected sires in a planned mating program.

WEST VIRGINIA UNIVERSITY

Agricultural Experiment Station

Colllege of Agriculture, Forestry, and Home Economics

H. R. VARNey, Director

MORGANTOWN 


\section{Locating Outstanding Bulls in Artificial Breeding}

\section{R. S. Dunbar, Jr., and G. Heebink}

\section{INTRODUCTION}

Previous reports by Henderson and Dunbar (2), Legates (3), and Robertson and Rendel (4) have shown that it is necessary to progeny test selected young bulls in artificial breeding in order to make maximum progress in the genetic improvement of a bull stud. They have also reported that it is essential that more young bulls be progeny tested than will be needed for replacement in the stud. Young bulls are tested by breeding them to a limited number of cows in artificial breeding and withholding them from further service until a number of their daughters have been tested for milk and butterfat production.

There are several ways to select young bulls to test in artificial breeding. One of the most promising is to select young bulls sired by bulls with outstanding proofs in artificial breeding. The dams of the young bulls should be the superior cows within the herds producing at high levels, and preference should be given to dams sired by bulls with outstanding proofs in artificial breeding. In large artificial breeding associations which have operated for a number of years, it may be possible to find such young bulls which are the result of chance matings. In many associations, however, dependence upon chance mating alone will not provide a sufficient number of desirable young bulls. Therefore, in most associations it is expedient to breed selected cows to selected bulls proven in artificial breeding and located either in the same association as the selected cows or other associations with which satisfactory arrangements can be made.

The following material describes a procedure followed in order to compile a list of outstanding bulls located in various studs and proven in artificial breeding which could be recommended to a sire selection committee as sires to be used for planned matings.

\section{PROCEDURE}

\section{Collection of Information}

A list of 22 selected bull studs was compiled by writing to managers of studs, to national breed association offices, to breed fieldmen, 
and to others familiar with studs throughout the country. Each individual contacted was asked to suggest studs which were likely to have bulls with desirable proofs in artificial breeding. The managers of the listed studs were then asked to provide a list of the bulls entering their stud between January 1, 1946, and January 1, 1951, and to indicate which of the bulls were still in service. Production information on the artificially sired daughters of these bulls was obtained by requesting Extension Dairymen of the respective states to forward a copy of the production averages of artificially sired daughters in their state tabulated by sire and year of freshening. Such tabulations had been sent to each state by the Dairy Husbandry Research Branch of the United States Department of Agriculture.

Of the 22 bull studs contacted, four did not have any active bulls which had entered the stud prior to January 1, 1951, and satisfactory production information pertaining to the bulls in eight other studs was not received. Necessary information was obtained on 225 bulls located in the remaining 10 studs. The distribution of all bulls, the bulls still in service, and the bulls selected by the analysis are presented in Table 1. (See Table 1, page 8.)

\section{Analysis}

The analysis of the data collected consisted of estimating the average production of an indefinitely large number of future daughters of each of the bulls within a stud. The records analyzed were adjusted for the years in which the daughters freshened and the adjusted daughter average of each sire was regressed towards their population average to an extent depending upon the number of tested daughters in the sire's daughter average. The bases for making such analyses are contained in previous publications by Henderson (1) and Robertson and Rendel (5). The computational steps employed in this instance are as follows:

Step 1. Compute the annual production averages using all the records of all daughters of all the bulls of the breed located in a given stud.

Step 2. Compute the average of the annual averages. This is the population average.

Step 3. Subtract the population average from each annual average. The differences are the respective annual environmental adjustments by which records for each year must be adjusted.

Step 4. Subtract the annual environmental adjustments from the respective annual averages for each sire.

Step 5. Recompute the sire averages using the adjusted averages for each year weighted by the number of records. 
Step 6. Subtract the population average from each of the adjusted sire averages; thus expressing each sire average as a deviation from the population average.

Step 7. Multiply each sire average, expressed as a deviation, by the quantity $\frac{n}{n+20}$ where $n$ is the number of tested daughters included in the sire average. (The quantity $\frac{n}{n+20}$ is the regression of the average production of an indefinitely large number of future daughters on the average production of $n$ tested daughters of the sire.) The product of this quantity and the sire's daughter average is the estimate of the production of future daughters of the sire relative to their contemporaries and thus provides a valid basis for comparing sires within a stud.

The following example illustrates the computational procedure.

\section{EXAMPLE TABULATION}

\begin{tabular}{|c|c|c|c|c|c|c|c|c|c|c|}
\hline \multirow{3}{*}{$\begin{array}{l}\text { Sire } \\
\text { No. }\end{array}$} & \multirow{3}{*}{$\begin{array}{c}\text { Freshening } \\
\text { Year }\end{array}$} & \multirow{3}{*}{$\begin{array}{l}\text { No. } \\
\text { Recs. }\end{array}$} & & & & \multicolumn{5}{|c|}{ Daughter average by sire } \\
\hline & & & \multicolumn{3}{|c|}{ M.E. $2 \times 305$} & \multirow{2}{*}{$\begin{array}{r}\text { No. } \\
\text { Dirs. }\end{array}$} & \multirow{2}{*}{\begin{tabular}{|c|} 
No. \\
Recs.
\end{tabular}} & \multirow[b]{2}{*}{ Milk } & \multirow[b]{2}{*}{ Test } & \multirow[b]{2}{*}{ Fat } \\
\hline & & & Milk & Test & Fat & & & & & \\
\hline \multirow{6}{*}{1} & 1948 & 1 & 7876 & 5.1 & 400 & & & & & \\
\hline & 1949 & 11 & 6103 & 4.8 & 294 & & & & & \\
\hline & 1950 & 30 & 6370 & 4.9 & 313 & & & & & \\
\hline & 1951 & 14 & 5660 & 4.7 & 264 & & & & & \\
\hline & 1952 & 13 & 6379 & 4.9 & 312 & & & & & \\
\hline & 1953 & 4 & 6012 & 4.8 & 287 & & & & & \\
\hline
\end{tabular}

$\begin{array}{lllll}39 & 73 & 6275 & 4.9 & 307\end{array}$

$\begin{array}{rrrrrr} & 1950 & 2 & 6976 & 4.7 & 331 \\ & 1951 & 12 & 7083 & 4.7 & 334 \\ 2 & 1952 & 19 & 7184 & 4.9 & 355 \\ & 1953 & 8 & 7846 & 5.0 & 390\end{array}$

$26 \quad 41 \quad 7186 \quad 4.9 \quad 350$

$\begin{array}{llllll} & 1952 & 4 & 6466 & 5.5 & 353 \\ 3 & 1953 & 3 & 7142 & 5.1 & 362\end{array}$

$\begin{array}{lllll}7 & 7 & 6755 & 5.3 & 357\end{array}$

(Continued on next page) 
Step 1. Annual Average for $1948=\frac{(1)(400)}{1}=400$

$$
\begin{aligned}
& 1949=\frac{(11)(294)}{11}=294 \\
& 1950=\frac{(30)(313)+(2)(331)}{30+2}=314
\end{aligned}
$$

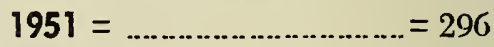

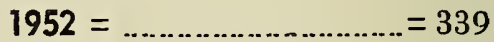

$$
\begin{aligned}
& 1953=\frac{(4)(287)+(8)(390)+(3)(362)}{4+8+3}=357
\end{aligned}
$$

Step 2. Population average $=\frac{400+294+\ldots \ldots \ldots \ldots \ldots+357}{6}=333$

Step 3. Annual adjustment for $1948=400-333=67$

$$
\begin{array}{r}
1949=294-333=-39 \\
1950=314-333=-19 \\
1951=296-333=-37 \\
1952=339-333=6 \\
1953=357-333=24
\end{array}
$$

\begin{tabular}{|c|c|c|c|c|}
\hline \multirow{2}{*}{ Sire 1} & & & & Adjusted fat \\
\hline & 1948 & 1 & $400-67$ & $=333$ \\
\hline & 1949 & 11 & $294-(-39)$ & $=333$ \\
\hline & 1950 & 30 & $313-(-19)$ & $=332$ \\
\hline & 1951 & 14 & $264-(-37)$ & $=301$ \\
\hline & 1952 & 13 & $312-6$ & $=306$ \\
\hline & 1953 & 4 & $287-24$ & $=263$ \\
\hline
\end{tabular}

Step 4 and 5.

Adjusted sire average $=39$ dtrs., 73 recs., 318 fat

$\begin{array}{lrrll}\text { Sire 2 } & 1950 & 2 & 331-(-19) & =350 \\ & 1951 & 12 & 334-(-37) & =371 \\ & 1952 & 19 & 355-6 & =349 \\ & 1953 & 8 & 390-24 & =360\end{array}$

Adjusted sire average $=26 \mathrm{dtrs}$, 41 recs., 359 fat

$\begin{array}{lllll}\text { Sire } 3 & 1952 & 4 & 353-6 & =347 \\ & 1953 & 3 & 362-24 & =338\end{array}$

Adjusted sire average $=7$ dtrs., 7 recs., 343 fat 
Step 6.

\begin{tabular}{ccccc}
$\begin{array}{c}\text { Sire } \\
\text { No. }\end{array}$ & $\begin{array}{c}\text { No. } \\
\text { Dtrs. }\end{array}$ & $\begin{array}{c}\text { Av. } \\
\text { Fat }\end{array}$ & $\begin{array}{c}\text { Pop. } \\
\text { Av. }\end{array}$ & $\begin{array}{c}\text { Av. Fat } \\
\text { as Deviation }\end{array}$ \\
\hline 1 & 39 & $318-333=$ & -15 \\
2 & 26 & $359-333=$ & 26 \\
3 & 7 & $343-333=$ & 10
\end{tabular}

\section{Step 7.}

Sire 1 average of future dtrs. $=\left(\frac{39}{39+20}\right)(-15)=(.60)(-15)=-10$ lbs. Sire 2 average of future dtrs. $=\left(\frac{2 \sigma}{26+20}\right)(26)=(.57)(26)=15$ lbs. Sire 3 average of future dtrs. $=\left(\frac{7}{7+20}\right)(10)=(.26)(10)=3 \mathrm{lbs}$.

The analysis as described thus far is particularly applicable to the comparison of bulls within the same stud. Inasmuch as the objective was to appraise bulls located in several different studs, it was also necessary to make some assumption concerning the cause of the differences among the population averages. In this instance it was assumed that the differences among population averages were due entirely to differences in average environments. From a theoretical view, this may not be the best assumption to make, but it does seem to be very nearly correct. From a practical standpoint it is expedient to assume that differences between population averages are due entirely to differences between average environments because one may compile a list of the bulls and their estimated future daughter averages expressed as deviations and treat them as being from the same population.

In the final appraisal of bulls which were still in service, those with at least 20 tested daughters and whose future daughters were predicted to exceed the average of their contemporaries by not less than 10 pounds were recommended to the sire selection committee for further investigation. Table 1 shows that of the 43 bulls still in service, there were eight bulls which fulfilled these minimum criteria.

\section{DISCUSSION}

In the application of this procedure it is assumed that each bull in a given stud has an equal opportunity to be mated to any cow in that association, that each bull has a single tested daughter in any herd, and that each daughter has a single, unselected record. It is also assumed 
that differences among the population averages are entirely a consequence of differences in average environments. Although the assumptions are not entirely valid, actual conditions in most areas approach the assumed conditions sufficiently well that inferences concerning the bulls are of value, and it seems certain that the errors are such that they would have little effect on the average merit of young bulls obtained through planned matings to A.B. ${ }^{1}$ proven bulls identified by such a procedure.

It should be noted that young bulls obtained for testing purposes through planned matings to A.B. proven bulls are highly selected. They are sired by highly selected A.B. proven bulls and are out of superior cows from superior cow families in high producing herds. By progeny testing two to three times as many young bulls as will be needed for replacements, and by re-selecting on the basis of the performance of their artificially sired progeny, it should be possible to develop a stud of highly selected A.B. proven bulls.

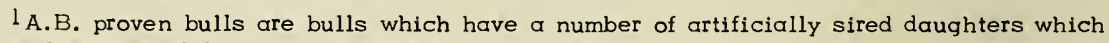
have been tested for milk and butterfat production.

TABLE 1. DISTRIBUTION OF BULLS ANALYZED

\begin{tabular}{ccccc}
\hline \hline Stud & $\begin{array}{c}\text { Number of Bulls } \\
\text { Entering Stud } \\
\begin{array}{c}\text { Setween 1/1/46 } \\
\text { and 1/1/51 }\end{array}\end{array}$ & $\begin{array}{c}\text { Number of Bulls } \\
\text { Remaining in } \\
\text { Service After } \\
1 / 1 / 55\end{array}$ & $\begin{array}{c}\text { Average } \\
\text { Number } \\
\text { Records per } \\
\text { Bull }\end{array}$ & $\begin{array}{c}\text { Selected A.8. } \\
\text { Proven Bulls* }\end{array}$ \\
\hline 1 & 33 & 2 & 48 & 0 \\
2 & 26 & 9 & 12 & 0 \\
3 & 31 & 4 & 30 & 2 \\
4 & 32 & 2 & 20 & 0 \\
5 & 14 & 3 & 75 & 2 \\
6 & 24 & 6 & 36 & 1 \\
7 & 12 & 6 & 53 & 1 \\
8 & 25 & 2 & 59 & 0 \\
9 & 16 & 5 & 96 & 1 \\
10 & 12 & 4 & 36 & 1 \\
Total & 225 & 43 & -- & 8 \\
\hline
\end{tabular}

* Selected A.B. proven bulls are those bulls with at least 20 tested A.B. daughters and whose future A.B. daughters are predicted to average at least 10 pounds of butterfat more than their contemporaries. 


\section{REFERENCES}

1. Henderson, C. R., "Selecting and Sampling Young Sires." Proc. 7th Ann. Conv. of Nat'l. Assn. of Artificial Breeders, p. 93-103, 1954.

2. Henderson, C. R., and R. S. Dunbar, Jr., "Improving Dairy Herds by Sampling Bulls." Farm Research, Vol. 18, No. 1, p. 3, 1952.

3. Legates, J. E., New Tools as Aids in Sire Selection. Mimeo. Presented at 1954 Meeting of American Dairy Science Association.

4. Robertson, A., and J. M. Rendel, "The Use of Progeny Testing with Artificial Insemination in Dairy Cattle." J. Genetics, Vol. 50, No. 1, 1950.

5. __...... "The Performance of Heifers Got by Artificial Insemination." J. Agr. Sci., Vol. 44, p. 184, 1954. 


